\title{
Revizyon kalça artroplastisinde tek/çift seans tedavi seçenekleri
}

\author{
Single/double session treatment options in revision hip arthroplasty
}

\author{
Barış Can Kuzuca ${ }^{1}$, Berk Güçlü ${ }^{2}$, Illker Çetin ${ }^{3}$ \\ ${ }^{1}$ Ankara Pursaklar Devlet Hastanesi, Ortopedi ve Travmatoloji Kliniği, Ankara \\ ${ }^{2}$ Ufuk Üniversitesi Dr. Rıdvan Ege Hastanesi, Ortopedi ve Travmatoloji Ana Bilim Dalı, Ankara \\ ${ }^{3}$ Medicana International Ankara Hastanesi, Ortopedi ve Travmatoloji Kliniği, Ankara
}

Total kalça artroplastisi, ileri evre kalça osteoartriti tedavisinde sıklıkla kullanılan bir cerrahidir. Ancak her cerrahi girişim gibi komplikasyonları da olabilen bir cerrahidir ve tedavisinde revizyon kalça artroplastisi uygulanmaktadır. Aseptik gevşeme, instabilite, aşınma, periprostetik kırıklar en sık nedenlerdirve genellikle tek aşama revizyon kalça artroplastisi ile tedavi edilir. Enfeksiyon ise bir diğer sık görülen revizyon nedenidir ve tedavide hem tek aşamalı revizyon hem de iki aşamalı revizyon cerrahisi uygulanabilir. Bu makalede revizyon cerrahi nedenleri ve tedavide tek veya iki aşamalı revizyon cerrahisi seçenekleri değerlendirilmiştir.

Anahtar sözcükler: revizyon kalça artroplastisi; aseptik gevşeme; instabilite; septik gevşeme; periprostetik kırık
Total hip arthroplasty is a frequent surgery which is used to treat severe hip osteoarthritis. However, like all surgical procedures, complications can be seen and revision hip arthroplasty should be applied. Aseptic loosening, instability, osteolysis, periprosthetic fractures are most common reasons and often treated by one stage revision arthroplasty. Infection is one the most frequent reason and can be treated both by single and two stage revision surgery. In this review, reasons of revision hip surgery, and single or two stage (staged) revision options were evaluated.

Key words: revision hip arthroplasty; aseptic loosening; instability; septic loosening; periprosthetic fracture
T otal kalça artroplastisi (TKA), ortopedi ve travmatoloji alanındaki eklem cerrahisinde, son yılarda artan sıklıkla uygulanan bir cerrahi tedavidir. Amerika Birleşik Devletleri'nde 10 yıl ve üzeri sürelerdeki başarı oranının \%90'dan fazla olduğu bildirilmiştir. ${ }^{[1]}$ Yüksek başarı oranına rağmen, çeşitli nedenler ile revizyon cerrahisi ihtiyacı da TKA'nın kaçınılmaz bir sonucudur. Artan primer TKA sayıları ile birlikte, revizyon TKA sayılarının da artmaya devam etmesi kaçınılmaz bir durumdur.

Total kalça artroplasti revizyon nedenleri, ekstrinsik, intrinsik ve sebebi bilinmeyen olarak üç grupta incelenebilir. Ekstrinsik nedenler kalça artroplastisi dışı nedenlerdir ve en sık lomber bölgeden kaynaklanır. Diğer nedenler arasında vasküler patolojiler ve abdominal-pelvik organ patolojileri sayılabilir. İntrinsik nedenler, kalça artroplastisinden kaynaklanan tüm nedenlerdir ve artroplasti komponentleri, eklem (sinovya) veya kalça çevresi yumuşak dokuları kaynaklı olabilir. En sık nedenler arasında; aseptik gevşeme, enfeksiyon, protez çevresi kırılar ve polietilen aşınması sayılabilir (Tablo 1). ${ }^{[2]}$

Aseptik gevşeme, TKA uygulamasından 10-20 yıl sonra görülebilen ve revizyon gerektiren bir durumdur.
Eklem sıvısının aşındırması, TKA komponentlerinin gevşemesinde en önemli etkendir. Protez komponentlerinin eklem ile birleştiği bölgede zaman içerisinde aşınma yıkıntıları oluşur. Bu yıkıntılar eklem sıvısındaki enflamatuvar komponentleri uyarır. Bu uyarı sonucunda zaman içerisinde başta 'Receptor Activator of Nuclear Factor' (RANK) sistemi olmak üzere çeşitli enflamatuvar sitokinleri aktive ederek komponente komşu kemikte osteolize neden olmaktadır. Osteoliz sonucu implantlarda gevşeme oluşmakta, bu durum da ağrılı bir ekleme neden olmaktadır (Şekil 1a). ${ }^{[3]}$ Aseptik gevşeme tedavisinde tek aşamalı revizyon cerrahisi ile gevşemiş komponentler değiştirilmektedir (Şekil 1b). Eğer komponentler stabil ise, sadece aşınmış liner değiştirilebilir. ${ }^{[2]}$

İnstabilite, TKA sonrası nadir görülse bile, revizyon cerrahisi gerektiren bir durumdur. Literatürde çeşitli oranlar olmasına rağmen, primer TKA sonrası protez çevresi çııı insidansı \%0,3-\%10, revizyon TKA sonrası \%28 olarak bildirilmiştir (Şekil 2a). ${ }^{[4]} 2012$ yılında Wera ve ark. tarafından yapılan bir sınıflandırmada instabilite nedenleri altı farklı başııta ele alınmıştır (Tablo 2). ${ }^{[5]}$

iletişim / Contact: Op. Dr. Barış Can Kuzuca • E-posta / E-mail: dr.bariskuzuca@gmail.com

ORCID iD: Barış Can Kuzuca, 0000-0002-3117-9037 • Berk Güçlü, 0000-0002-3705-3435 • Illker Çetin, 0000-0003-1713-047X 
Tablo 1. Ağrılı kalça artroplastisi nedenleri ${ }^{[2]}$

\begin{tabular}{ll}
\hline Intrinsik nedenler & Ekstrinsik nedenler \\
\hline Enfeksiyon & Lomber radikülopati \\
Aseptik gevşeme & Spinal stenoz \\
iliopsoas impingement veya tendinit & Damarsal kladikasyo \\
Periprostetik kırık & Periferik arter hastalığı \\
Trokanterik bursit & Abdominal veya pelvik kitle \\
Metal sinoviti & Psikolojik nedenler \\
Zıt lokal doku reaksiyonu & \\
Nadir nedenler (tümör, çimento göçü) &
\end{tabular}

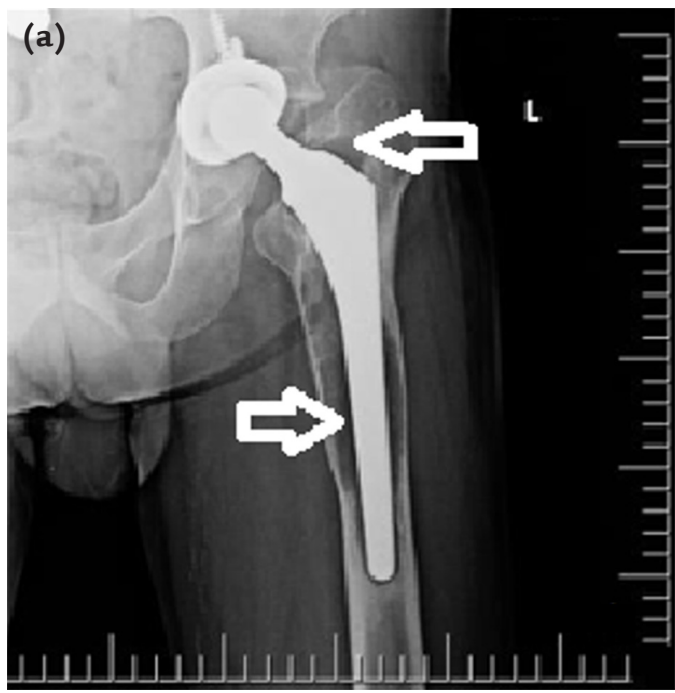

(b)

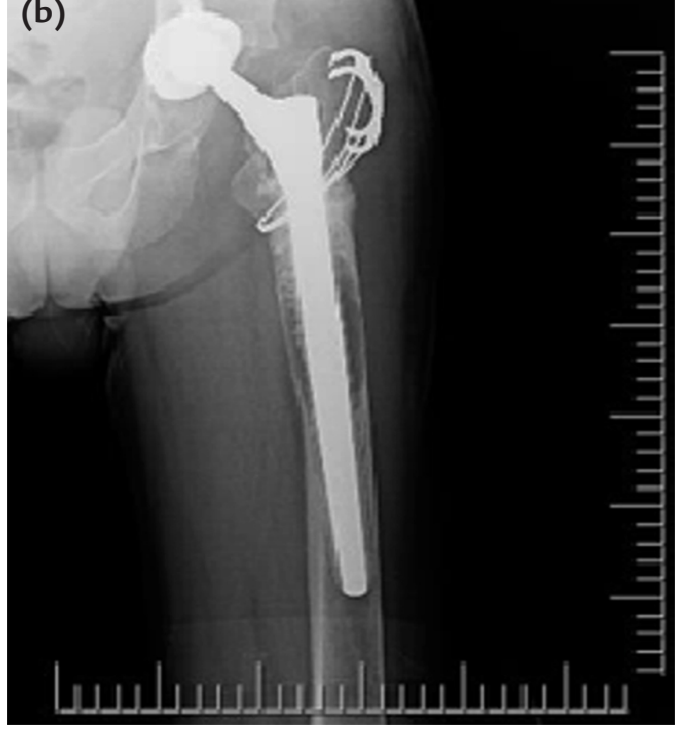

Şekil 1. a, b. Femoral stemde gelişen aseptik gevşeme örneği (ok uçları, osteoliz bölgeleri) (a). Tek aşama revizyon cerrahisi ile femoral stemin trokanterik kayma osteotomisi ile çıkartılması, kaviter boşalma gösteren alanların oto-allo greftler ile desteklenmesi ve uzun saplı tam yüzey poröz kaplı femoral steme tespit edilip, trokanterik osteotominin ise serklaj telleri ile sabitlenmesi (b).
Tablo 2. Instabilite sınıflaması ${ }^{[5]}$

\begin{tabular}{cl}
\hline Tip & Instabilite nedeni \\
\hline 1 & Asetabulum pozisyon hatası \\
2 & Femur pozisyon hatası \\
3 & Abduktor yetmezliği \\
4 & Impingement \\
5 & Polietilen aşınmasına bağlı geç çıkık \\
6 & Etiyolojisi bilinmeyen
\end{tabular}

İnstabilite tedavisinde; asetabular yerleşim bozukluklarında, tek aşamalı revizyon cerrahisi ile asetabular komponent yeniden düzenlenmelidir. Cerrahi esnasında anteversiyon düzenlenmelidir. Ranawat ve Maynard'ın 1991 yılında yaptıkları çalışmalarında, kombine versiyon kadınlarda $45^{\circ}$, erkeklerde $20-30^{\circ}$ olarak tanımlamışlardır ve halen bu oranlar kullanılmaktadır. ${ }^{[6]}$ Eğer asetabular kemik deposu yetersiz ise, modüler liner değişimi düşünülebilir. Femoral yerleşim bozukluklarında ise tek aşamalı revizyon cerrahisi ile femoral stem, mümkün olduğunca fazla kemik stoğu bırakarak çıkartılmalı ve uygun versiyon sağlanarak uzun stem femoral komponent ile değiştirilmelidir (Şekil 2b). Polietilen aşınmasında ise tek aşamalı revizyon cerrahisi ile polietilen ve femur başı değiştirilmelidir. ${ }^{[2]}$

Metal-metal komponent kullanımı da uzun dönemde revizyon gerektiren sorunlara neden olabilmektedir. Geçmiş 10 yıllık dönemde geniş çaplı ( $\geq 36 \mathrm{~mm}$ ) metal-metal komponent kullanımının monoblok kobalt krom soketlerin gevşemesi, yumuşak doku iritasyonu veya 'zıt lokal doku reaksiyonu'na neden olabildiği gösterilmiştir. ${ }^{[7]}$ Tedavide, tek aşamalı revizyon cerrahisi ile reaksiyon sonucu oluşan kistik psödotümörün ve nekrotik alanın uzaklaştırılması için geniş doku debridmanı; komponentler stabil ise metal linerın polietilen ile femur başının ise seramik ile değişimidir. Komponentler stabil değil ise veya polietilen ve seramik linerların uygulanmasına müsait değil ise, asetabular ve femoral komponentlerin de değiştirilmesidir. Eğer komponentler stabil ise, metal-metal komponentlerin sadece bir tanesi de değiştirilebilir. Tedavide çimentolu veya çimentosuz komponentlerin birbirlerine üstünlüğü gösterilememiştir. ${ }^{[8]}$

Periprostetik eklem enfeksiyonu, önemli morbiditeye neden olan, eklem fonksiyonu için olumsuz sonuçlara yol açan, fiziksel kısıtlılığa neden olabilen ve önemli mortalite oranlarına sahip olan bir tıbbi sorun olmaya devam etmektedir. ${ }^{[2]}$ Rölatif (göreceli) enfeksiyon oranları 2020 yılı itibarı ile \%2,0 ila \%2,4 olarak bildirilmektedir. ${ }^{[9]}$ En sık bilinen etken stafilokoklardır ve olguların yaklaşık \%50'sinden sorumludur. Diğer bakteriler ve 

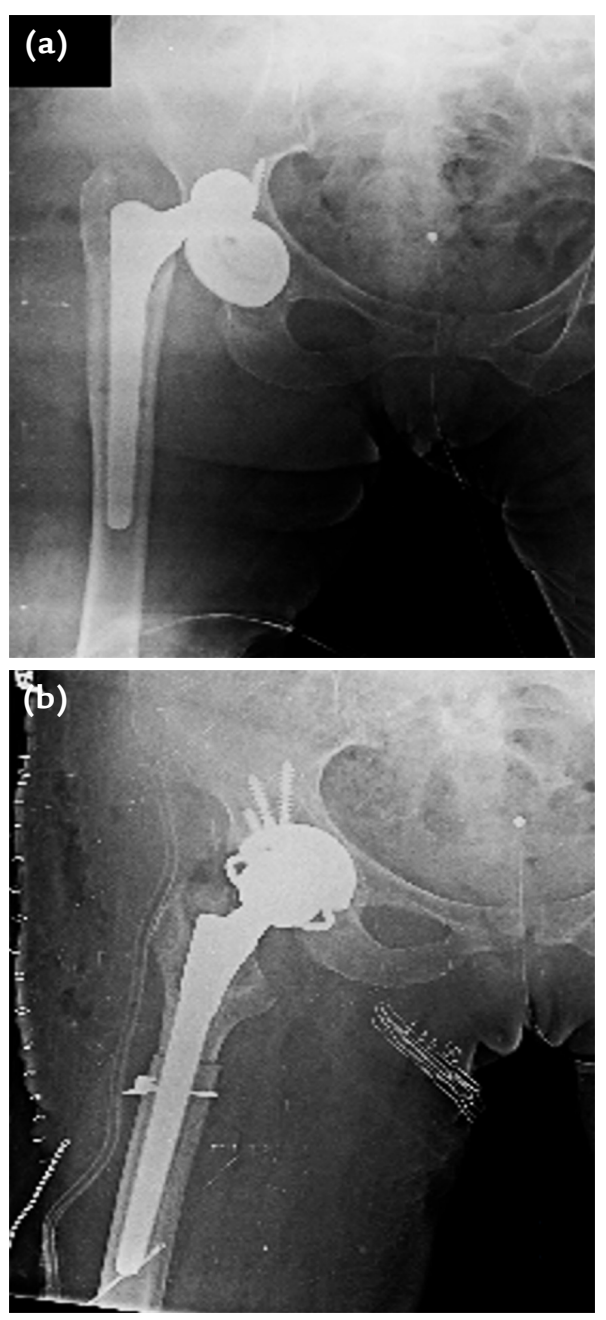

Şekil 2. a, b. İnstabilite sonucu periprostetik çıkık gelişen total kalça artroplastisi grafisi örneği (a). Tek aşama revizyon cerrahisi ile femoral kısaltma sonrasında asetabular ve femoral komponentlerin değiştirilmesi sınırlandırıcı (constrained) liner (içlik) uygulanması sonrası kalça ön-arka grafisi (b).

mantarların da etken olabileceği unutulmamalıdır. ${ }^{[10]}$ Olguların yaklaşık \%20'sinde birden fazla patojen belirlenebilir ve pek çoğu metisiline dirençli Staphylococcus aureus veya anaeroblar içermektedir. ${ }^{[11]}$ Yaklaşık \%7 oranında kültür-negatif patojen belirlenebilir. ${ }^{[12]}$ S.aureus tarafindan protez komponentleri üzerinde oluşan biyofilm tabakası, tedavide ciddi güçlükler yaratmaktadır. ${ }^{[10]}$

Pek çok profilaktik yöntem bulunmasına rağmen; implant ömrünün uzaması, hasta takip sürelerinin uzaması ve yeni belirteçlerin kullanılmaya başlanması ile enfeksiyon tespiti kolaylaşmıştır. Özellikli hasta gruplarında (diyabet, persistan idrar yolu enfeksiyonu, immün yetmezlik, ileri yaş vb.); enfeksiyonların daha baskın olması, uygunsuz antibiyotik kullanımına bağlı
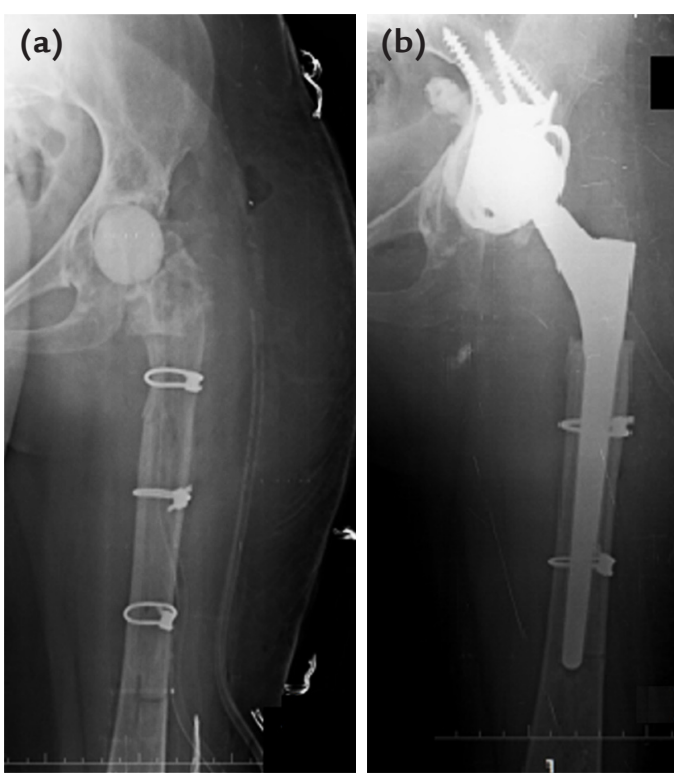

Şekil 3. a, b. Birinci aşama revizyon cerrahisi ile komponentlerin çıkartılması ve yer tutucu uygulanması örneği (a). İkinci aşama revizyon cerrahi ile asetabuluma kafes, çimentolu kısıtlayıcı (constrained) liner, Wagner çimentosuz yekpare stem ve serklaj telleri (Dall-Miles) uygulanması örneği (abduktor mekanizmadaki kayıp dikkat çekicidir) (b).

olarak mikroorganizmaların gün geçtikçe daha virülan olması ve çoklu revizyon ile eklemde oluşan ileri kemik stoğu kaybı ile genel eklem fonksiyonunun bozulması tedavide güçlük çıkarabilmektedir. ${ }^{[12]}$

Periprostetik eklem enfeksiyonlarında tedavinin amacı; enfeksiyonu tedavi etmek, nüksü (rekürrensi) engellemek, ağrısız ve fonksiyonel bir eklem oluşturmaktır. Total kalça artroplastisi sonrası derin doku enfeksiyonu için en iyi tedavi seçeneği 1970'lerden beri tartışmalıdır. ${ }^{[13]}$ Altın standart tedavi olarak kabul edilen iki aşamalı revizyon cerrahisinde birinci aşamada komponentlerin çıkartılması ile antibiyotik içeren yer tutucu uygulamasıdır (Şekil 3a). Antibiyoterapi uygulanan refrakter dönem sonrası enfeksiyonun giderildiğinden emin olduktan sonra ikinci aşama cerrahide revizyon komponentleri uygulanır (Şekil 3b). Ancak güncel literatürde farklı yöntemler de tanımlanmaya başlanmıştır. ${ }^{[14]}$

Erken dönem periprostetik enfeksiyonlarda, debridman ve implant koruma (DAiR) da bir tedavi seçeneğidir. Ancak etkili olması için bazı durumların bir arada olması gerekmektedir. Del Pozo ve Patel tarafindan 2009 yılında yayımlanan kılavuzda, DAiR'nin etkili olabilmesi için implantın üç aylık süreçte uygulanması, semptomların üç haftadan kısa olması, enfeksiyonun hematojen olması, apse veya sinus yolunun olmaması, implantların stabil olması ve enfeksiyonun çoklu ilaç 
dirençli, virülant veya mantar olmaması olarak tanımlanmıştır. ${ }^{[10]} \mathrm{Bu}$ şartları sağlayan olgularda başarı oranı \%50-80 olarak bildirilmiştir. ${ }^{[15]}$ Yapılan 42 hastalık bir çalışmada, belirtilen şartları sağlayan 34 hastada başarı oranı $\% 90$ olarak bildirilmiştir. ${ }^{[16]}$

Periprostetik eklem enfeksiyonu için tek aşamalı revizyon tedavisinde, mevcut enfekte implantlar çıkartılmakta, geniş bir debridman yapıldıktan sonra yeni protezler aynı seansta uygulanmaktadır. Bu yöntemin en önemli avantajı, hastanın ikinci aşama revizyon cerrahisini beklemeden fonksiyonel tedaviye kavuşmasıdır. Ek olarak tek cerrahiye ihtiyaç duyulması, daha kısa antibiyoterapi kullanımı ve düşük maliyet de bu yöntemin avantajlarındandır. ${ }^{[17]} \mathrm{Bu}$ yöntemin en önemli endikasyonu, kültür veya genetik olarak etkenin kesin olarak tanımlanmış olmasıdır. Ayrıca hastada yeterli kemik stoğunun olması ve yara iyileşmesinin de mümkün olması önemlidir. Kültür negatifliği, hastada sistemik sepsis olması, nörovasküler dokuların enfeksiyonu, yara kapanmasına izin vermeyen aşırı yumuşak doku tutulumu ve ileri virülan mikroorganizma varlığında tek aşama revizyon cerrahisi kontrendikedir. ${ }^{[18]}$

Cerrahi teknikte cerrahın uygun gördüğü yaklaşım ile ekleme ulaşıldıktan sonra implantlar, mümkün olan en fazla kemik stoğu bırakacak şekilde çıkartılır. Tüm kanamayan dokular ve ilgili kemik doku radikal olarak eksize edilir. Pulsatif lavaj ile geniş bir yıkama yapılır. Intramedüller kanalın polimerik biguanid hidroklorid ile yıkanması tavsiye edilmektedir. Yıkama solüsyonlarının en az 10-15 dakika süre ile dokuya temas etmesi önerilmektedir. ${ }^{[18]}$ Yeniden implant uygulamadan önce cerrahlar eldiven ve önlüklerini değiştirmeli ve yeni bir steril alan yaratılmalıdır. Tek aşamalı cerrahide, kemik kaybını gidermek için allogreft kullanımı tartışmalıdır. Enfeksiyon varlı̆̆ında allogreft yerine PMMA (polimetilmetakrilat) içeren kemik çimentoları veya tantalum augmentler kullanımı önerilmektedir. ${ }^{[14]}$ Yapılan çalışmalarda, tantalumun diğer implantlara göre stafilokoklara daha dirençli olduğu bildirilmiştir. ${ }^{[19]}$ Ancak, yapılan 37 hastalık bir çalışmada, kadavradan alınan antibiyotik emdirilmiş kemik greftleri kullanıldığında 35 hastada enfeksiyon görülmemiştir. ${ }^{[20]}$ Defekt için uygun revizyon sistemi kullanılmalıdır. Femoral revizyon için de çimentolu sistem kullanımı önerilmektedir. Çimento kullanılırken dikkatli olunmalıdır. Çimentoya antibiyotik eklerken, çimentonun yapısını bozmamak için antibiyotik miktarı çimentonun \%10'undan fazla olmamalıdır. ${ }^{[21]}$ Ayrıca, hastada sistemik toksisite yaratmamak için ilgili antibiyotik dozu dikkatlice ayarlanmalıdır. Antibiyotikler toz formda ve bakterisidal özellikte olmalıdır. Antibiyotiklerin yan etkileri bilinmeli ve ilgili tedbirler alınmalıdır. Çimentosuz komponentler de kullanılabilir. Yapılan 12 hastalık bir çalışmada, çimentosuz komponent kullanılarak yapılan tek aşamaIı revizyonlarda üç yıllık takiplerde başarı oranı $\% 83,3$ olarak bildirilmiştir. ${ }^{[22]}$

Tek aşamalı cerrahi sonrası, sistemik antibiyoterapi 10-14 gün devam etmelidir. Streptokok varlı̆̆ında bu süreç uzatılabilir. illk iki hafta intravenöz (iV) antibiyoterapi uygulanmalı sonrasında oral idame tedavisine geçilmelidir. ${ }^{[23]}$ Uygun antibiyoterapi için enfeksiyon hastalıkları uzmanlığı tarafından görüş alınmalıdır. Cerrahi sonrası erken mobilizasyona izin verilmelidir.

Tek aşamalı cerrahide başarısızlık oranı \%9 ila \%20 olarak bildirilmiştir. Komplikasyon olarak persistan enfeksiyon, instabilite ve yara yeri enfeksiyonları bildirilmiştir. ${ }^{[18]}$

Güncel literatürde tek aşamalı revizyon cerrahisi başarı oranları yüksek olarak bildirilmektedir. Yapılan bir çalışmada, 17 tek aşama ile 44 iki aşama revizyon cerrahisi karşılaştırılmış ve enfeksiyon kontrol oranları tek aşama için \%82, iki aşama için \%75 olarak bildirilmiştir. ${ }^{[24]}$ Başka bir çalışmada ise 38 tek aşama ile 46 iki aşama revizyon cerrahisi karşılaştırılmış ve tek aşama için enfeksiyon eradikasyon oranı $\% 100$, iki aşama için \%97,8 olarak bildirilmiştir. ${ }^{[25]}$ İsveç kalça artroplasti kayıtları ile ilgili yapılan bir başka çalışmada ise, 404 tek aşama ile 1250 iki aşama revizyon artroplastisi karşılaştırılmış ve 15 yıllık takipte birbirlerine karşı herhangi bir üstünlük saptanamamıştır. ${ }^{[26]}$

Periprostetik eklem enfeksiyonunun iki aşamalı revizyon cerrahisinde, enfekte komponentlerin çıartılması, antibiyotik içeren yer tutucu uygulanması ve belirli bir süre antibiyoterapi sonrası yeni komponentlerin uygulanması altın standart tedavi olarak belirtilmiştir. ${ }^{[13]}$ Rekonstrüksiyon için yeterli kemik stoğunun olmadığı olgularda ve etkenin bilinmediği, çoklu veya dirençli olduğu olgularda, yeterli yumuşak doku örtüsünün olmadığı, sinus yolu varlığı ve çimentosuz komponent kullanımı tercihinde endikedir. Fakat, iki aşamalı revizyonun ciddi morbidite ve mortaliteye neden olması, hasta tarafindan iyi tolere edilememesi ve 2. aşama sonunda fonksiyon kaybı yaratması bilinen dezavantajlardır. ${ }^{[14]}$

İki aşamalı revizyon cerrahisinin birinci aşaması mevcut komponentlerin çıkartılması ile debridman ve antibiyotik içeren yer tutucu uygulamasından oluşur. Yer tutucunun amacı, lokal etki ile dokuya antibiyotik salınımını sağlamaktır. Yer tutucu için birden fazla yöntem mevcuttur. Eklemli yer tutucular yük taşımaya izin vermekte iken, statik yer tutucular eklemli değildir ve yük taşımaya izin vermez. ${ }^{[2]}$

Antibiyotik emdirilmiş statik yer tutucular eklemli olmadıkları için, kırık veya çıkık gibi mekanik komplikasyonlar sık görülmez. Bunlar, çok kısıtlı da olsa yük 
vermeye izin verebilir; ancak doku kasılmasına neden olduğu için ikinci aşama cerrahide zorluk yaratabilir. Statik yer tutucular, tek parça olarak veya boncuk dizisi olarak hazırlanabilir. Tek parça olanların yerleşimi ve çıkartılması, boncuk dizilerine kıyasla daha zordur.[14] Çimentoya eklenecek olan antibiyotiklerin çeşitli kombinasyonları mevcuttur. En sık kullanılan kombinasyonlardan biri tobramisin ve vankomisindir. Bu kombinasyon özellikle etken mikroorganizma bilinmediği zaman etkilidir. Önemli noktalardan biri de uygulanacak olan antibiyotiğin, etken mikroorganizmanın minimum inhibitör konsantrasyonunun üzerinde olması gerekliliğidir. Genellikle $40 \mathrm{~g}$ kemik çimentosu PMMA içerisine $3 \mathrm{~g}$ vankomisin ve 3,6 g tobramisin kombinasyonu kullanılmaktadır; genellikle hem asetabuluma hem de femoral kanala uygulanması önerilmektedir. Yer tutucunun şeklini vermek için çimento tabancası kullanılabilir veya buna el ile şekil verilebilir. En önemli noktalardan biri, kemik kaybına neden olmamak için çimentonun kemik ile entegre olmasını engellemektir. ${ }^{[2]}$

Eklemli yer tutucular, asetabulum ile femur arasındaki ilişkiyi koruyarak fonksiyon korunumu sağlamaktadır. Hazır olarak kullanılabilen bu yer tutucular da antibiyotik salınımı sağlamaktadır. Fakat bunlar, kırık ve çıkık gibi sık görülen komplikasyonlara neden olur. ${ }^{[2]}$ Yapılan 131 hastalı bir çalışmada, eklemli yer tutucu kullanılan hastalarda enfeksiyon eradikasyon oranı iki yıllık takipte \%92, beş yıllık takipte $\% 88$ olarak bildirilmiştir. ${ }^{[27]}$

illk aşama cerrahi sonrası iV antibiyoterapi pek çok kılavuzda önerilmektedir. Kültür sonucu sonrası uygun antibiyoterapi başlanmalıdır. Eğer uygun bir kültür sonucu alınamamışsa, ampirik antibiyoterapi uygulanmalıdır. Çeşitli kılavuzlarda bu süre 6-12 hafta olarak önerilmektedir. ${ }^{[2]}$ Yapılan 144 hastalı bir çalışmada, 12 haftalık tedavinin altı haftalık tedaviye göre bir üstünlüğü olmadığı gösterilmiştir. ${ }^{[28]} 17$ hastalı başka bir çalışmada ise, erken oral tedaviye geçmenin olumsuz etkisi olmadığı gösterilmiştir. ${ }^{[29]}$ Ayrıca literatürde lokal antibiyoterapinin yeterli olduğunu savunan görüşler de mevcuttur. ${ }^{[2]}$

Antibiyoterapi sonrası serolojik belirteçlerin (eritrosit sedimentasyon hızı, C-reaktif protein - CRP) normale dönmesi ve aspirasyon sonrası kültür negatifliği sağlandıktan sonra 2. aşama uygulanabilir. Kemik defektlerinin durumuna göre uygun komponentler seçilip uygulanmalıdır. ${ }^{[14]}$

Periprostetik kırıklar ise revizyon cerrahisi gerektiren bir diğer sorundur. Literatürde kalça periprostetik kırık oranı \%0,1 ila \%18 olarak bildirilmiştir. Cerrahi sırasında femoral kırık oranı \%1,7 iken, 20 yıl sonunda kırık gelişme ihtimali \%3,5'tir. Özellikle ileri yaşta ve kadın cinsiyette daha sık görülmektedir. Genellikle düşük enerjili travma sonucu oluşmaktadır (Şekil 4a). Osteoporoz, romatoid artrit ve revizyon cerrahisi ek risk faktörleridir. Periprostetik femur kırı̆ı için en sık kullanılan sınıflama sistemi Vancouver sınıflamasıdır. Tip A kırıkları apofız kırıklarıdır. Tedavi, kırık yerine göre değişkenlik gösterir. Trokanter minör kırıkları konservatif tedavi edilirken trokanter majör kırıkları için cerrahi gerekebilir. Tip B kırıkları, implant veya implant desteği çevresinde oluşan kırıklardır. Üç alt tipi bulunmaktadır. Tedavide kırık tipine göre plak-vida veya serklaj ile tespit ya da uzun stem revizyon içerir. Tip $C$ kırıklar ise implantın distalinde gelişen kırıklardır ve uzun stem ile revizyon gereklidir (Tablo 3) (Şekil 4b). ${ }^{[30]}$
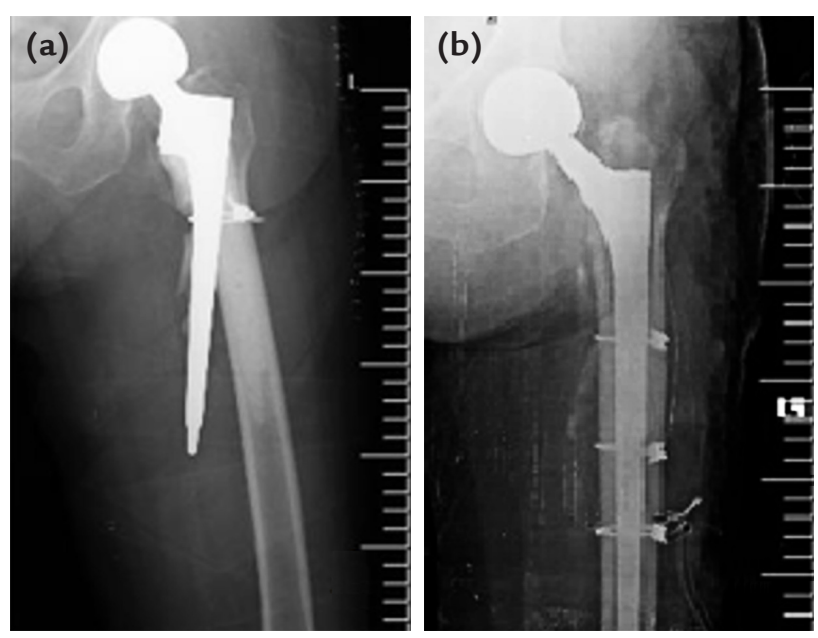

Şekil 4. a, b. Çimentolu bipolar protez uygulanması sonrasında, erken dönemde protez çevresi kırık ve instabilite örneği (a). Tek aşama revizyon cerrahisi uzatılmış trokanterik osteotomi ile femoral stem ve çimentoların çıkartılması ve uzun sapI çimentosuz poröz kaplı Wagner femoral stem ve osteotomi hattının serklaj ile tespit ve bipolar baş ile tedavi edilmesi (b).

Tablo 3. Vancouver sınıflaması ve tedavi seçenekleri[ ${ }^{[30]}$

\begin{tabular}{cll}
\hline Tip & Yer & Tedavi \\
\hline A & Trokanter etrafi & \\
AG & Trokanter majör & $\begin{array}{l}\text { Konservatif veya gevşek } \\
\text { stemde cerrahi }\end{array}$ \\
AL & Trokanter minör & Konservatif \\
\hline B & Stem etrafı veya hemen distali \\
B1 & Stabil stem & ARIF (serklaj, plak) \\
B2 & Gevşek stem & Uzun stem revizyon \\
& & (ARiF gerekebilir) \\
B3 & Kemik kaybı ile & Uzun stem revizyon \\
& gevşek stem & (greft gerekebilir) \\
\hline C & İmplantın distali & Uzun stem revizyon veya ARiF \\
\hline ARiF, açık redüksiyon internal fiksasyon.
\end{tabular}




\section{KAYNAKLAR}

1. Clohisy JC, Calvert G, Tull F, McDonald D, Maloney WJ. Reasons for Revision Hip Surgery: a Retrospective Review. Clin Orthop Relat Res 2004;429:188-92. Crossref

2. Cashman J, Goyal N, Parvizi J. The Hip. Preservation, Replacement and Revision, Volume 2. Maryland USA: Data Trace Publishing Company; 2015.

3. Abu-Amer Y, Darwech I, Clohisy JC. Aseptic Loosening of Total Joint Replacements: Mechanisms Underlying Osteolysis and Potential Therapies. Arthritis Res Ther 2007;9(Suppl 1):S6. Crossref

4. Parvizi J, Picinic E, Sharkey PF. Revision Total Hip Arthroplasty for Instability: Surgical Techniques and Principles. J Bone Joint Surg Am 2008;90(5):1134-42. https://pubmed.ncbi. nlm.nih.gov/18451408/

5. Wera GD, Ting NT, Moric M, Paprosky WG, Sporer SM, Della Valle CJ. Classification and Management of the Unstable Total Hip Arthroplasty. J Arthroplasty 2012;27(5):710-5. Crossref

6. Ranawat CS, Maynard MJ. Modern Techniques of Cemented Total Hip Arthroplasty. Tech Orthop 1991;6(3):17-25. Crossref

7. Schmalzried TP. Metal-metal Bearing Surfaces in Hip Arhroplasty. Orthopaedics 2009;32(9). Crossref

8. Matharu GS, Eskelinen A, Judge A, Pandit HG, Murray DW. Revision Surgery of Metal-on-metal Hip Arthroplasties for Adverse Reactions to Metal Debris. A clinical Update. Acta Orthop 2018;89(3):278-88. Crossref

9. Kurtz SM, Lau E, Watson H, Schmier JK, Parvizi J. Economic Burden of Periprosthetic Total Infection in United States from 2005 to 2030. J Bone Surg Am 2007;89;780-5.

10. Del Pozo JL, Patel R. Infection Associated with Prosthetic Joints. N Engl J Med 2009;361(8):787-94. Crossref

11. Marculescu CE, Cantey JR. Polymicrobial Prosthetic Joint Infections: Risk Factors and Outcome. Clin Orthop Relat Res 2008;466(6):1397-404. Crossref

12. Berbari EF, Marculescu C, Sia I, Lahr BD, Hanssen AD, Steckelberg JM, Gullerud R, Osmon DR. Culture-negative Prosthetic Joint Infection. Clin Infect Dis 2007;45(9):1113-9. Crossref

13. Leonard HAC, Liddle AD, Burke O, Murray DW, Pandit H. Single or Two Stage Revision for Infected Total Hip Arthroplasty? A Systematic Review of the Literature. Clin Orthop Relat Res 2014;472(3):1036-42. Crossref

14. Malhotra R. Mastering Orthopaedic Techniques -Total Hip Arthroplasty, 1st ed. India: Jaypee Brothers Medical Publishers Ltd.; 2012.

15. Shan L, Shan B, Graham D, Saxena A. Total Hip Replacement: A Systematic Review and Meta-analysis on Mid-term Quality of Life. Osteoarthritis Cartilage 2014;22(3):389-406. Crossref

16. Sendi P, Lötscher PO, Kessler KB, Graber P, Zimmerli W, Clauss M. Debridement and Implant Retention in the Management of Hip Periprosthetic Joint Infection. Bone Joint J 2017;99-B(3):330-6. Crossref
17. ZaharA, Webb J, Gehrke T, KendoffD. One-stage Exchange for Prosthetic Joint Infection of the Hip. Hip Int 2015;25(4):3017. Crossref

18. Zahar A, Gehrke TA. One Stage Revision for Infected Total Hip Arthroplasty. Orthop Clin N Am 2016;47(1):11-8. Crossref

19. Schildhauer TA, Robie B, Muhr G, Köller M. Bacterial Adherence to Tantalum Versus Commonly Used Orthopedic Metallic Implant Materials. J Orthop Trauma 2006;20(7):476-84. Crossref

20. Winkler H, Kaudela K, Stoiber A, Menschik F. Bone Grafts Impregnated with Antibiotics as a Tool for Treating Infected Implants in Orthopedic Surgery -One Stage Revision Results. Cell Tissue Bank 2006;7(4):319-23. Crossref

21. Fink $B$, Vogt $S$, Reinsch $M$, Büchner $H$. Sufficient Release of Antibiotic by a Spacer 6 Weeks After Implantation in Twostage Revision of Infected Hip Prostheses. Clin Orthop Relat Res 2011;469(11):3141-7. Crossref

22. Yoo JJ, Kwon YS, Koo K-H, Yoon KS, Kim Y-M, Kim HJ. Onestage Cementless Revision Arthroplasty for Infected Hip Replacements. Int Orthop 2009;33(5):1195-201. Crossref

23. Kilgus DJ, Howe DJ, Strang A. Results of Periprosthetic Hip and Knee Infections Caused by Resistant Bacteria. Clin Orthop Relat Res 2002;404:116-24. Crossref

24. Choi H-R, Kwon Y-M, Freiberg AA, Malchau H. Comparison of One-Stage Revision with Antibiotic Cement Versus TwoStage Revision Results for Infected Total Hip Arthroplasty. J Arthroplasty 2013;28(8):66-70. Crossref

25. Klouche S, Leonard P, Zeller V, Lhotellier L, Graff W, Leclerc P, Mamoudy P, Sariali E. Infected Total Hip Arthroplasty Revision: One- or Two-stage Procedure? Orthop Traumatol Surg Res 2012;98(2):144-50. Crossref

26. Svensson K, Rolfson O, Karrholm J, Mohaddes M. Similar Risk of Re-Revision in Patients after One- or Two-Stage Surgical Revision of Infected Total Hip Arthroplasty: An Analysis of Revisions in the Swedish Hip Arthroplasty Register 1979-2015. J Clin Med 2019;8(4):485. Crossref

27. Chalmers BP, Mabry TM. Abdel MP. Berry DJ, Hanssen AD, Perry KI. Two-Stage Revision Total Hip Arthroplasty With a Specific Articulating Antibiotic Spacer Design: Reliable Periprosthetic Joint Infection Eradication and Functional Improvement. J Arthroplasty 2018;33(12):3746-53. Crossref

28. Bernard L, Legout L, Zürcher-Pfund L, Stern R, Rohner P, Peter R, Assal M, Lew D, Hoffmeyer P, Uçkay I. Six Weeks of Antibiotic Treatment is Sufficient Following Surgery for Septic Arthroplasty. J Infect 2010;61(2):125-32. Crossref

29. Darley ES, Bannister GC, Blom AW, Macgowan AP, Jacobson SK, Alfouzan W. Role of Early Intravenous to Oral Antibiotic Switch Theraphy in the Management of Prosthetic Hip Infection Treated with One- or Two-stage Replacement. J Antimic Chemother 2011;66(10):2405-8. Crossref

30. Capone A, Congia S, Civinini R, Marongiu G. Periprosthetic Fractures: Epidemiology and Current Treatment. Clin Cases Miner Bone Metab 2017;14(2):189-96. Crossref 